\title{
Impact of climate on juvenile mortality and Armillaria root disease in lodgepole pine
}

\author{
by W. Richard Dempster ${ }^{1}$
}

\begin{abstract}
Variable and sometimes high levels of mortality in lodgepole pine (Pinus contorta Dougl. ex Loud. var. latifolia Engelm.) planted in western Alberta have raised awareness of the need to forecast and ameliorate risks to reforestation success. Mortality and health of regeneration during the 12 years following harvest were monitored and evaluated in relation to climate, site and silvicultural treatments. Results suggest that physiological stress related to evapotranspiration is the most prevalent cause of overall juvenile mortality and susceptibility to Armillaria root disease in planted pine. Mortality and disease not only increase at higher rates of drying during the growing season, but an opposite effect is also demonstrated whereby they decrease with increasing spring temperatures. Mechanical site preparation aimed at countering mortality and disease of planted stock with improved soil conditions appears to have good potential for ameliorating adverse climatic effects in juvenile stands.
\end{abstract}

Keywords: climate, juvenile mortality, Armillaria root disease, lodgepole pine, reforestation

\section{RÉSUMÉ}

Les taux de mortalité variables et parfois élevés constatés dans les plantations de pin tordu (Pinus contorta Dougl. ex Loud. var. latifolia Engelm.) de l’ouest de l'Alberta font ressortir l'importance de prévoir et d’améliorer les chances de succès des reboisements. Létude cherche à mettre en lien la mortalité et la santé de la régénération durant les 12 années suivant la coupe avec le climat, la qualité de station et les pratiques sylvicoles. Les résultats laissent voir que cést le stress physiologique lié à lévaporation qui est responsable de la mortalité juvénile et de la susceptibilité au pourridié-agaric (Armillaria) chez les pins en plantation. Non seulement la mortalité et la maladie augmentent-elles lorsque la sécheresse est plus importante au cours de la saison de croissante, mais on observe également un effet contraire et donc une diminution lorsque la température printanière augmente. La scarification mécanique visant à contrer la mortalité et la maladie chez les semis en améliorant la préparation du sol semble une option prometteuse pour améliorer les conditions climatiques adverses dans les jeunes peuplements.

Mots-clés : climat, mortalité juvénile, Armillaria , pourridié-agaric, pin tordu, reboisement

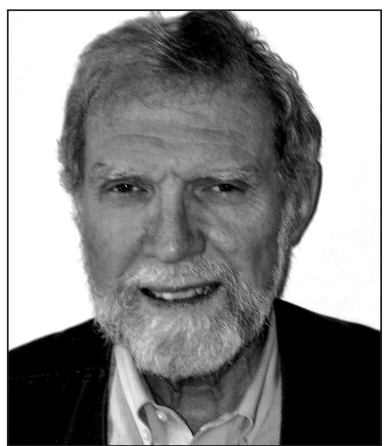

W. Richard Dempster

\section{Introduction}

The potential for increased tree mortality associated with climate change is now recognized for forests worldwide. Forecasts and interpretations vary widely. Van Mantgem et al. (2009) showed that background mortality rates in western North American forests have increased rapidly in recent decades and concluded that regional warming and consequent increases in water deficits are likely contributors to the increases in tree mortality rates. Similar conclusions were drawn by Peng et al. (2011) from a study of permanent sample plots distributed across the Canadian boreal forest from Quebec to Alberta. Chen and Luo (2015), using data from permanent sample plots in Alberta and Saskatchewan, reported declines in net above- ground biomass between 1958 and 2011 resulting from mortality and reduced growth. They attributed the decline to persistent warming and decreasing water availability. Conversely, Thorpe and Daniels (2012) found no evidence of warming temperatures influencing the rate of tree mortality in mature forests in the Alberta foothills, and Zhang et al. (2015) showed that competition has played a stronger role in observed changes than has climate. Several studies have suggested that predicted climate trends will eventually result in major changes to ecosystem distribution and forest landscapes in western Canada (e.g., Hogg 1994, Schneider et al. 2009). Predictions for the future of lodgepole pine range from regional habitat elimination to improved productivity (e.g., Alberta Forest Genetic Resources Council 2006, Monserud et al. 2008). Climate warming and drying have been shown to have opposing and complex effects on tree radial growth. Warm and dryer winters and longer growing seasons will promote growth, but hotter and drier summers would reduce it (Chhin et al. 2008). It has long been established that climatic injury to lodgepole pine results when spring frost in the ground prevents moisture from rising in the trees (Henson 1952).

In the studies mentioned above little or no attention has been paid to juvenile conditions in stands under 20 years of

${ }^{1}$ Forest Growth Organization of Western Canada, fRI Research, 1176 Switzer Drive, Hinton AB T7V 1V3; wr.dick.dempster@gmail.com 
age or impacts of silviculture, and the extent to which the latter might ameliorate adverse climate effects. Huang et al. (2004) reported that site productivity of juvenile post-harvest lodgepole pine stands increased after a simple regimen of logging and drag scarification in Alberta. Landhäusser (2009) investigated effects of slash removal and mechanical site preparation on lodgepole pine seedling regeneration in the Alberta Upper Foothills sub-region. He demonstrated beneficial effects of site preparation on early survival and growth of planted stock, and on ingress and growth of natural regeneration. Cortini et al. (2010) predicted that young lodgepole pine plantations established following mechanical site preparation in the sub-boreal zone of British Columbia will benefit in the short-term from longer growing seasons as a result of global warming. Mechanical site preparation was demonstrated to improve soil-water relations in clear-cut areas planted with lodgepole pine (Fleming et al. 1996).

Lodgepole pine has wide soil and climatic tolerances and is well-adapted to regenerating Alberta sites following harvesting (Johnstone 1976). Yet recent modelling by Erickson et al. (2015) suggested that lodgepole pine forests in Alberta are experiencing climatically driven declines in conditions suitable for tree regeneration. Pathological health and mortality threats to lodgepole pine have been identified in the province for some time. Nordin (1954) noted that pure stands are particularly liable to infection by Atropellis canker (Atropellis piniphila (Weir) Lohman \& Cash), blister rusts (Cronartium spp.) and Armillaria root disease (Armillaria spp.). Mountain pine beetle (Dendroctonus ponderosae Hopkins), although historically restricted by climatic conditions, is endemic (Powell 1966). Cerezke (1973) made recommendations for using clearcutting as a means of controlling Warren's root collar weevil (Hylobius warreni Wood). Ives and Rentz (1993) identified a variety of factors affecting survival of immature lodgepole pine, including rodents, western gall rust (Endocronartium harknessii (J.P. Moore) Y. Hirat), Armillaria root disease, Warren's root collar weevil and blister rusts. Mountain pine beetle attack has been a major concern over the last 10 years, and forest management strategies have been developed and implemented to limit its effects (Alberta Sustainable Resource Development 2007). These strategies involve harvesting to reduce the size and number of susceptible stands and to normalize the age-class structure of pine forests. However, reforestation continues to rely primarily on regeneration of harvested pine stands back to lodgepole pine and, until recently, mortality and health issues in young regenerated stands have not been major concerns (Dempster and Meredith 2014). Greater concern has been expressed in British Columbia where health problems in planted lodgepole pine deemed "free-to-grow" are extensive and are expected to increase with climate change (Mather et al. 2010).

Links between pathogen dynamics, host susceptibilities and climate are widely reported in the literature. Cereske (1973) found a link between temperature in the larval feeding zone of Warren's root collar weevil, rate of weevil development and numbers of adults in Alberta clear-cut areas. Woods et al. (2005) found a clear relationship between a local increase in summer precipitation and an unprecedented Dothistroma needle blight epidemic in British Columbia. Carroll et al. (2006) produced convincing evidence that much of the Canadian boreal forest will become climatically available to the mountain pine beetle in the near future. Heineman et al. (2010) evaluated the influence of climate, site, location, and treatment factors on young lodgepole pine in British Columbia, and found evidence of increasing risk of damage with warming and drying climatic conditions. They noted that risks from several serious agents, including western gall rust, Atropellis canker and mountain pine beetle, increased as temperature of the coldest month (MCMT) became warmer.

Armillaria root disease, most commonly caused by Armillaria ostoyae (Romagne.) Herink, is one of the main causes of mortality in young lodgepole pine in Alberta (Mallett 1990). Its incidence is likely to increase with warm and dry conditions. Under a warming climate, low soil temperature will not limit rhizomorph growth to the extent it does at present (La Porta et al. 2008). Whilst ability of the pathogen to sporulate, spread and infect is affected by temperature and moisture, factors that stress host trees directly may be just as critical to successful invasion of host tissues. It seems likely that the disease will become more severe in future wherever Armillariasusceptible tree species are subjected to increased levels of climate stress (Klopfenstein et al. 2009). Site preparation techniques that bring infected roots and stumps to the surface or avoid exposing transplants to infected stumps have been shown to reduce losses of spruce to Armillaria attack in Ontario (Whitney and Dumas 1994).

Since the year 2000 annual and bi-annual re-measurements of a field trial of regenerated lodgepole pine (referred to below as the "RLP" trial) have monitored the effects of site and treatment factors on juvenile stand development following harvesting and planting in the Alberta foothills. Dempster and Meredith (2014) noted high levels of mortality in planted stock on some sites. Armillaria root disease was implicated in much of the mortality, and survival continued to diminish 11 years after planting. They suggested that increasingly adverse climate conditions may exacerbate juvenile mortality and susceptibility to pathogens, and that there may be both the need and opportunities to reduce the impacts of common pests through modifications to reforestation practice. An earlier study of naturally regenerated stands up to 30 years-old showed changes in the levels of various mortality factors (including Armillaria) over time, but no overall trend between mortality rates and age. The authors expressed concern over the persistence of juvenile mortality (Ives and Rentz 1993).

The RLP study described below investigates the effects of climate on juvenile mortality and disease in planted lodgepole pine, and the extent to which such risks can be ameliorated by management interventions. The reported analyses address the following questions:

1. What climate factors influence juvenile mortality and Armillaria root disease in lodgepole pine planted following harvest?

2. Can juvenile mortality be predicted from climate variables?

3. Can reforestation practices be selected to reduce juvenile mortality and root disease, and their negative impacts on reforestation success?

The juvenile mortality considered here includes mortality from all causes: known, suspected and unknown. Investigation into specific pathogens is limited to Armillaria root disease because of its high incidence. The high incidence not only resulted in it being considered a priority by forest managers sponsoring the study, but also provided a larger sample of plots for assessing tree infection rates than are available for any other individual pathogen. 
Mortality results from the RLP trial are also compared with mortality data extracted from the published report of the Ives and Rentz (1993) trial that assessed factors affecting survival of natural regeneration within the same geographic area. The data are currently of interest because the RLP trial, where ingress of natural regeneration is still occurring, is not yet sufficiently advanced to fully assess relationships of climate to mortality in naturally regeneration. They also provide an opportunity to determine the extent to which the trends observed in the RLP trial could be replicated with independent data collected over a different time period, and over an age range extending to 30 years. Site, treatment and response differences between the two trials are not all known or quantified, and this constrains any comparison. The data and a comparison of trends with those shown by the RLP trial are outlined in the Materials and Methods and Discussion sections below. The Results section of this paper is confined to the RLP trial.

\section{Materials and Methods Experimental design}

The RLP field trial was laid out in a replicated split-plot design involving 102 one-hectare whole plots, each with four sub-plots, distributed in recently clear-cut areas throughout the Upper and Lower Foothills natural sub-regions. Fig. 1a shows the study area and sampling locations in relation to highways, populated areas and natural sub-regions. The study area is defined by natural sub-region boundaries. For administrative and cost-sharing purposes the whole plots were allocated in groups of six among 10 area-based forest tenures in proportion to each pine-leading forest area. This allowed distribution of the plots across a representative range of pine sites, with an even representation of six planting densities. Sites were classified according to the system established for west-central and southwestern Alberta ecosites by Archibald et al. (1996), Beckingham et al. (1996) and Corns et al. (2005). Preliminary classification was used to distribute the plots across the range of pine site types being operated by tenure holders. More detailed ecological site information was subsequently collected. The ecosite classification of each plot included assessment of soil moisture and nutrient regimes. The plots lie between latitudes $51^{\circ}$ to $55^{\circ}$ north and longitudes $114^{\circ}$ to $120^{\circ}$ west (see Fig. 1a). Whole plots were planted in 2001 with lodgepole pine at densities of $0,816,1111,1600$, 2500 and 4444 trees per ha following clearcutting and either no additional mechanical site preparation, drag scarification or mounding. The 17 non-planted plots were not used in this study. Six other planted plots were excluded because of accidental damage (mostly aerial over-spraying with herbicide). Table 1a shows the distribution of the remaining 79 plots which form the basis for this study by natural sub-region, soil nutrient and soil moisture classes.

The RLP experimental design controlled planting density and the subsequent weeding treatment, but not site preparation methods applied before planting. The forest companies participating in the trial used a variety of site preparation equipment and methods at their discretion and according to their normal best practices. Site preparation effects may therefore be confounded with site variation. Table $1 \mathrm{~b}$ shows the distribution of whole plots by site preparation method, planting density and natural sub-region.

The split sub-plot design ensured an equal distribution of weeding treatments. Each whole-plot listed in Table 1 was divided into four sub-plots, each 0.25 ha in area, to accommodate four treatment combinations: weed, thin, weed and thin, and control. Weeding involved either chemical or mechanical reduction of hardwood, shrub and herbaceous competition during the first six years following planting. Thinning to target densities of crop trees, commenced in 2012, is also part of the trial's experimental design, and periodic measurements are ongoing, but the present study is confined to assessment of pre-thinning responses. For all analytical purposes in the present study, except estimation of probabilities of plot attack by Armillaria, the two non-weeded sub-plots were combined as one, as were the two weeded sub-plots.

Tree measurements were confined to a buffered 0.1 ha area at the centre of each sub-plot. Mortality was assessed annually on all planted trees, and the condition of live trees bi-annually from 2001 to 2012. Health assessments, including identifiable insect and disease infections and supported with crew training and audits by forest health experts, were commenced in 2009. Field crews assigned health codes ${ }^{2}$ to live and dead trees showing symptoms of abiotic, disease and insect damage. In the case of dead trees, where the cause of death was not apparent the tree was dug up to ascertain the presence of root pathogens. A maximum of two health factors was recorded for each tree, prioritized by likelihood to cause or have caused mortality. For the present study, overall cumulative mortality was recorded to 2012, and health was assessed at 11 to 12 years after planting.

Supplementary mortality data were extracted from the report published by Ives and Rentz (1993) on factors affecting survival of natural regeneration in west-central Alberta. In the original study mortality rates were recorded three times at three-year intervals, spanning a nine-year period from 1981 to 1990 . The initial stand ages varied from 6 to 25 years and averaged 14 years. Data on survival proportions in each of 67 sample units were compiled. Sampling locations were manually extracted from detailed maps contained in the study report. Periodic mean annual mortality and climate averages were calculated for the whole period.

\section{Analyses}

This study examines contemporaneous trends based on variation in periodic mortality, disease and climate between sample plots, rather than trends over time. Climate values for each sample location were obtained using the software package ClimateWNA (Wang et al. 2016). Climate variables extracted from ClimateWNA were averaged over 12 years (2001-2012) for the RLP trial. Cumulative mean annual mortality percent of planted stock was calculated as of 2012 based on the elapsed time since planting (11 to 12 years). For the analysis of root disease, the percentages of trees (live plus dead) with Armillaria root infection were compiled from health data collected in 2011 and 2012.

The relationships of 14 annual climate variables listed in Table 2 to mortality and Armillaria root disease were evaluated by a variety of techniques. Following initial investigation of annual climate variables, analyses were extended to seasonal variables. All climate variables were compiled internally by the ClimateWNA model except PET and CMI which were

\footnotetext{
${ }^{2}$ See Table S1 in Supplementary Materials
} 


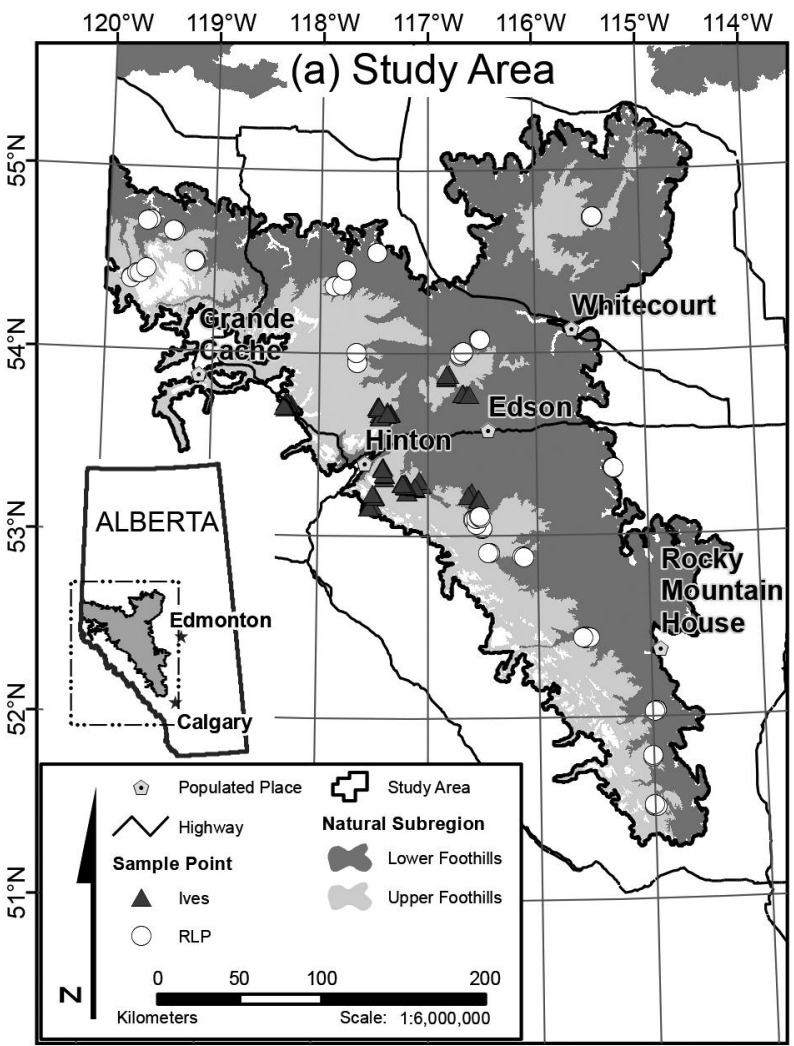

(b) Reference Evaporation (mm)

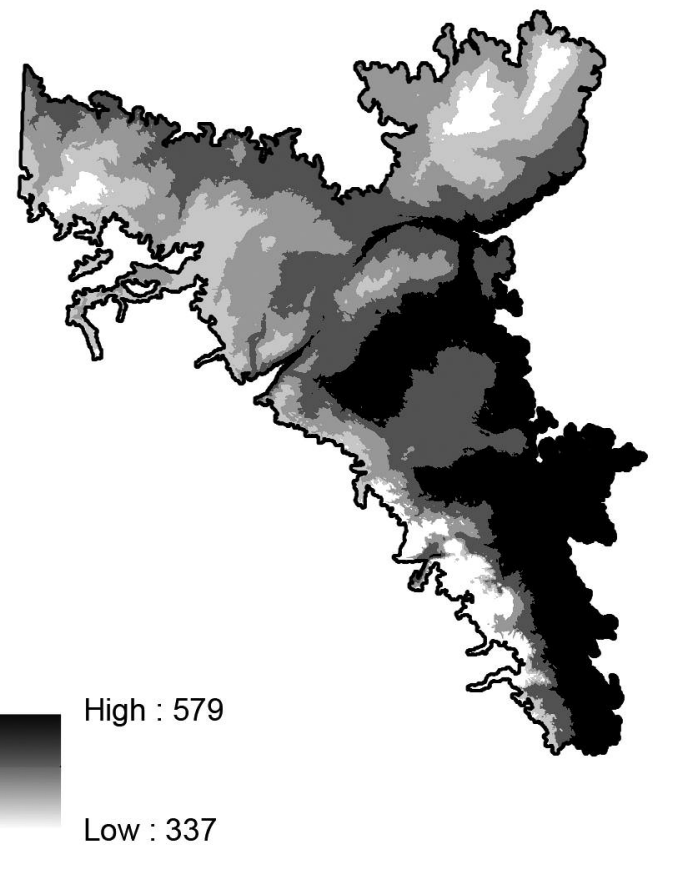

(c) Average Spring Temperature $\left({ }^{\circ} \mathrm{C}\right)$

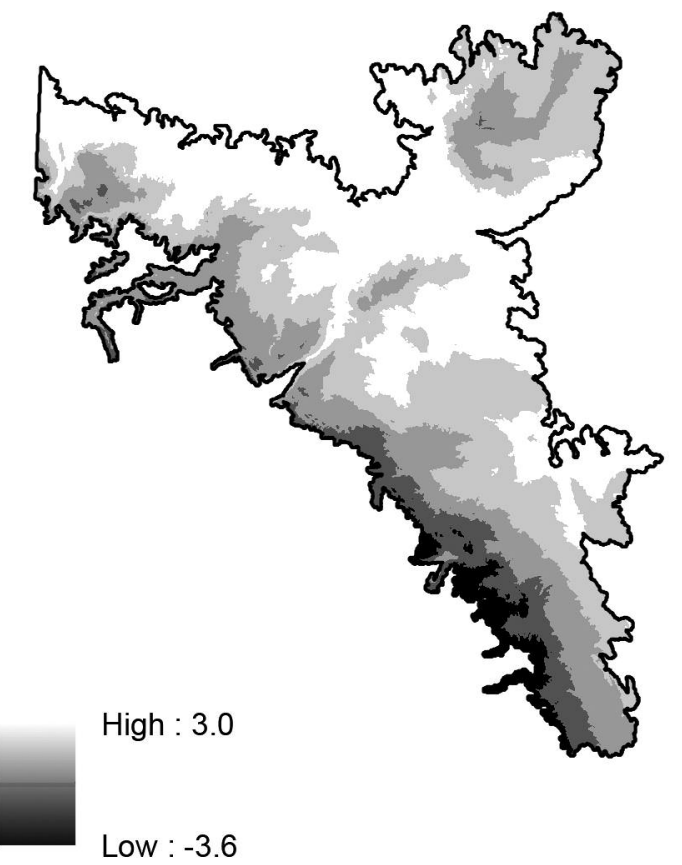

(d) Mortality Risk

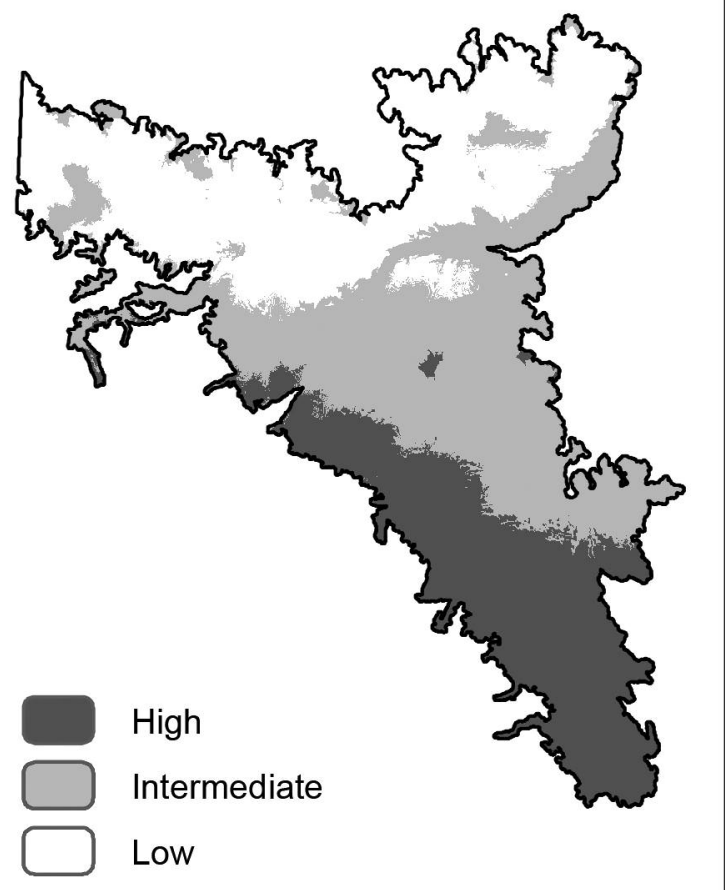

Fig. 1. Spatial variation of mortality risk and related climate variables: (a) study area and regeneration sampling locations; (b) Hargreaves reference evaporation; (c) average spring temperature for the decade 2001-2010; and (d) mortality risk for juvenile lodgepole pine estimated from the combined effects of annual evaporation and spring temperature. (Projection: NAD83 UTM Zone 11N; base map data provided by the Government of Alberta under the Alberta Open Government Licence, November 2014). 
Table 1. Distribution of whole plots by site and treatment classes.

(a) by natural sub-region and soil regime

Natural sub-region/soil nutrient regime

\begin{tabular}{|c|c|c|c|c|c|c|c|}
\hline \multirow{2}{*}{$\begin{array}{l}\text { Soil } \\
\text { moisture } \\
\text { regime }\end{array}$} & \multicolumn{3}{|c|}{ Lower Foothills } & \multicolumn{3}{|c|}{ Upper Foothills } & \multirow[b]{2}{*}{ Total } \\
\hline & Poor & Medium & Rich & Poor & Medium & Rich & \\
\hline Submesic & 3 & 0 & 0 & 1 & 2 & 0 & 6 \\
\hline Mesic & 0 & 9 & 7 & 6 & 17 & 7 & 46 \\
\hline Subhygric & 5 & 2 & 2 & 8 & 2 & 3 & 22 \\
\hline Hygric & 1 & 2 & 0 & 0 & 2 & 0 & 5 \\
\hline Total & 9 & 13 & 9 & 15 & 23 & 10 & 79 \\
\hline
\end{tabular}

(b) by natural sub-region, site preparation method and planting density

Natural sub-region/site preparation method

\begin{tabular}{|c|c|c|c|c|c|c|c|}
\hline \multirow{2}{*}{$\begin{array}{l}\text { Density } \\
\text { (trees/ha) }\end{array}$} & \multicolumn{3}{|c|}{ Lower Foothills } & \multicolumn{3}{|c|}{ Upper Foothills } & \multirow[b]{2}{*}{ Total } \\
\hline & None & Drag & Mound & None & Drag & Mound & \\
\hline 816 & 5 & 1 & 1 & 2 & 4 & 3 & 16 \\
\hline 1111 & 4 & 1 & 1 & 2 & 4 & 4 & 16 \\
\hline 1600 & 4 & 1 & 2 & 2 & 4 & 3 & 16 \\
\hline 2500 & 4 & 1 & 1 & 2 & 4 & 4 & 16 \\
\hline 4444 & 3 & 1 & 1 & 3 & 4 & 3 & 15 \\
\hline Total & 20 & 5 & 6 & 11 & 20 & 17 & 79 \\
\hline
\end{tabular}

calculated as described by Hogg (1997). PET and Eref are approximations of potential evapotranspiration or drying calculated primarily from monthly temperatures. Both assume that evapotranspiration decreases as temperatures approach freezing and that none occurs below freezing. PET is defined as the loss of water vapour from healthy vegetation on soils with adequate soil moisture (Hogg 1997). Eref is the reference atmospheric evaporative demand for a grass surface with no soil moisture restriction as calculated in the ClimateWNA model.

Simple correlation and linear regression analyses were used to explore and compare trends of climate variables with mortality percentages between the 79 whole plots. Relationships of climate variables with the natural logarithm of mortality percent were evaluated for statistical significance, strength of the correlation, and trend. The same approach was used for initial exploration of root infection percentages in the 61 whole plots that were attacked by Armillaria (i.e., contained at least one infected tree). The logarithmic transformation of percentages was effective in reducing skewness and kurtosis, and improving homoscedasticity and the distributions of residuals. Correlation matrices were produced for both the RLP and the Ives datasets to evaluate the relationships between climate variables, and principal component analysis and spin plots assisted in visualizing correlations between climate variables. ${ }^{3}$ The effects of climate variables on the probabilities of RLP sample plots being attacked by Armillaria were estimated by logistic regression. The probabilities

${ }^{3}$ See Table S2 and Fig. S1 and S2 in Supplementary Materials were calculated from the number of sub-plots (0 to 4$)$ containing at least one tree infected by Armillaria within each whole plot.

REML (restricted maximum likelihood) least squares methodology and multiple response fitting (MANOVA) techniques (SAS Institute 2002) were used to examine the effects of site, treatment and climate variables on tree mortality, and on levels of root disease in plots attacked by Armillaria. These techniques permitted examination of effects taking into account the unbalanced and layered design of the RLP trial. Again, natural logarithmic transformation of the response variables proved effective. Partial regression leverage plots provided insight into effects of individual climate variables within fitted least square models.

MANOVA fitting techniques were used in analyses of site and treatment effects. These analyses recognized two layers in the experimental design: between-plot effects and the withinplot weeding effect. Between-plot effects included natural sub-region, soil nutrient, soil moisture, site preparation, planting density, and climate. The weeding effect was assessed by specifying two response variables in the analyses of variance, one for each of the two weeding treatments. It has only one degree of freedom per response function because there are only two weeding treatments (i.e., effectively two subplots per whole plot since sub-plots with the same weeding treatment were combined). Therefore, exact F-values could be calculated and were used for testing both between-plot and within-plot effects. The mortality tests were based on all 79 whole-plots. The MANOVA Armillaria tests, which investigated differences in rates of tree infection in plots once 
(a) Tree mortality \%

\begin{tabular}{llcccc} 
Climate variable & & r-value & R-square & Prob $^{\mathbf{2}} \mathbf{F}^{\mathbf{3}}$ & AIC $^{\mathbf{4}}$ \\
\hline PET & Hogg's yearly potential evapotranspiration & 0.463 & 0.214 & $<.0001$ & -81.4 \\
ERef & Hargreaves reference evaporation & 0.404 & 0.163 & 0.0003 & -76.6 \\
DD 0 & degree-days below 0 ${ }^{\circ}$ C & 0.373 & 0.139 & 0.0009 & -74.5 \\
MCMT & mean coldest month temperature & -0.351 & 0.123 & 0.0019 & -73.1 \\
CMI & Hogg's climate moisture index & -0.311 & 0.097 & 0.0062 & -70.8 \\
MAT & mean annual temperature & -0.258 & 0.067 & 0.0243 & -68.3 \\
PAS & precipitation as snow & -0.236 & 0.056 & 0.0400 & -67.4 \\
CMD & Hargreaves climatic moisture deficit & 0.231 & 0.053 & 0.0447 & -67.2 \\
MAP & mean annual precipitation & -0.205 & 0.042 & 0.0752 & -66.3 \\
AHM & annual heat-moisture index & 0.115 & 0.013 & 0.3243 & -64.1 \\
MWMT & mean warmest month temperature & 0.080 & 0.006 & 0.4940 & -63.5 \\
MSP & mean annual summer precipitation & 0.070 & 0.005 & 0.5454 & -63.4 \\
DD $>5$ & degree-days above 5 ${ }^{\circ} \mathrm{C}$ & -0.069 & 0.005 & 0.5553 & -63.4 \\
SHM & summer heat-moisture index & 0.040 & 0.002 & 0.7313 & -63.2 \\
\hline
\end{tabular}

(b) Plot and tree attack by Armillaria

Probability of plot attack

$\%$ of trees infected

\begin{tabular}{|c|c|c|c|c|c|c|c|}
\hline Climate variable & $\mathbf{R}^{2}(\mathbf{U})^{5}$ & Prob $>\mathrm{ChiSq}^{6}$ & Trend & r-value & R-square & Prob $>$ F & AIC \\
\hline PET & 0.126 & $<.0001$ & + & 0.578 & 0.334 & $<.0001$ & 43.1 \\
\hline Eref & 0.116 & $<.0001$ & + & 0.577 & 0.333 & $<.0001$ & 43.2 \\
\hline $\mathrm{DD}<0$ & 0.113 & $<.0001$ & + & 0.485 & 0.235 & $<.0001$ & 51.4 \\
\hline CMI & 0.113 & $<.0001$ & - & -0.572 & 0.327 & $<.0001$ & 43.7 \\
\hline MCMT & 0.092 & $<.0001$ & - & -0.419 & 0.176 & 0.0009 & 55.9 \\
\hline MAP & 0.087 & $<.0001$ & - & -0.525 & 0.275 & $<.0001$ & 48.2 \\
\hline MAT & 0.085 & $<.0001$ & - & -0.430 & 0.185 & 0.0006 & 55.2 \\
\hline CMD & 0.074 & $<.0001$ & + & 0.641 & 0.411 & $<.0001$ & 35.7 \\
\hline PAS & 0.061 & $<.0001$ & - & -0.211 & 0.045 & 0.1056 & 64.8 \\
\hline AHM & 0.036 & 0.0001 & + & 0.398 & 0.158 & 0.0017 & 57.2 \\
\hline $\mathrm{DD}>5$ & 0.020 & 0.0036 & - & -0.237 & 0.056 & 0.0683 & 64.0 \\
\hline MSP & 0.001 & 0.4940 & ns & -0.429 & 0.184 & 0.0006 & 55.3 \\
\hline SHM & 0.001 & 0.6082 & ns & 0.363 & 0.132 & 0.0044 & 59.0 \\
\hline MWMT & 0.000 & 0.7470 & ns & -0.107 & 0.011 & 0.4169 & 66.8 \\
\hline
\end{tabular}

${ }^{1}$ r-value = correlation coefficient;

${ }^{2} \mathrm{R}$-square $=$ proportion of the variation in $\ln$ mortality $\%$ attributed to the climate variable;

${ }^{3}$ Prob $>\mathrm{F}=$ significance probability for the F-ratio (probabilities of 0.05 or less are typically considered as evidence that the relationship is significant);

${ }^{4} \mathrm{AIC}=$ Akaike information criterion, used to judge which or how many parameters to use in a least-squares regression model; lower scores indicate a superior fit;

${ }^{5} \mathrm{R}^{2}(\mathrm{U})=\mathrm{R}$-square $(\mathrm{U})$ : uncertainty coefficient (represents the proportion of the total uncertainty attributed to the variable by the logistic regression);

${ }^{6} \mathrm{Prob}>\mathrm{ChiSq}=$ probability of the difference between the logistic regression model fitted with and without the climate variable having arisen by chance; ns = non-significant.

attacked (as distinct from probabilities of plots being attacked), were restricted to 46 whole plots in which both the weeded and non-weeded sub-plot contained at least one infected tree. This avoided null values of the transformed response variables. The Tukey-Kramer HSD method was used to test for differences among mean responses to categorical site and treatment variables.

The maps in Fig. 1 for reference evaporation (b), average spring temperature (c), and mortality risk (d), were developed from a grid of $500 \mathrm{~m} \mathrm{x} 500 \mathrm{~m}$ cells covering the study area. Latitudes and longitudes of the centre points plus average elevations for each cell were extracted, and input into ClimateWNA to estimate decadal averages of reference evaporation (Eref) and average spring temperature (Tave_sp) for the period 2001 to 2010 .

\section{Results}

Effect of climate on mortality of planted stock

Correlations and simple linear regressions of individual annual climate variables with the natural logarithm of mortality percent are summarized in Table 2a. Eight variables are identified as statistically significant (probability of chance occurrence 0.05 or less): PET, Eref, $\mathrm{DD}<0, \mathrm{MCMT}, \mathrm{CMI}$, MAT, PAS and CMD. PET and Eref show positive and relatively strong trends with mortality. Both are approximations of potential evapotranspiration or drying. Fig. 2 illustrates the predicted trend of mortality with PET, which shows the strongest trend with mortality in Table $2 \mathrm{a}$ (R-square 0.21 and AIC -81.4), based on the regression equation:

(1) Ln mortality $\%=-4.05461+0.010793 \times$ PET 


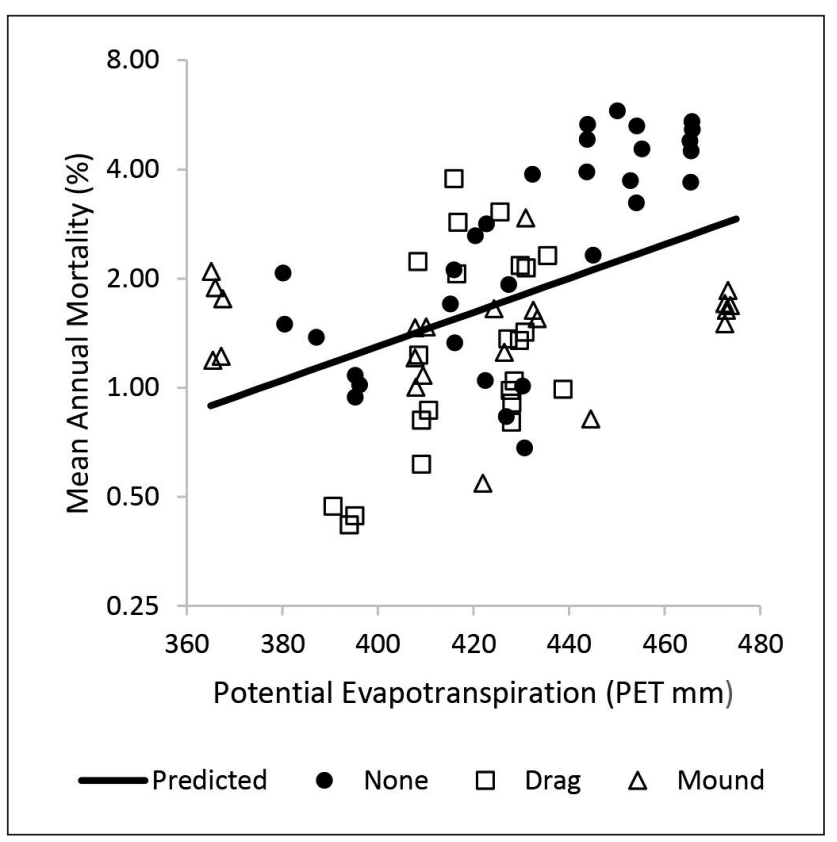

Fig. 2. Trend of planted stock mortality with annual potential evapotranspiration. Observed mortality values for sample plots are shown relative to the trend predicted by Equation 1 (solid line). Plots are differentiated by site preparation method. Note the logarithmic mortality axis.

The CMD and CMI indices, which take into account both potential evapotranspiration and precipitation, show slightly weaker correlations with mortality than do PET and Eref, which estimate only potential evapotranspiration. CMD and CMI appear to be no better predictors of mortality than do PET or Eref. This perhaps reflects their estimation not taking into account local soil, site and treatment factors affecting actual moisture availability. Mortality decreases significantly with increasing MCMT. Other measures of annual temperature show weaker trends.

A negative correlation between mortality and temperature was found to be statistically significant for average winter (December, January, February) temperatures $(\mathrm{P}<0.0001)$, marginally significant for average spring (March, April, May) temperatures $(P=0.06)$, and non-significant for summer (June, July, August) and autumn (September, October, November) averages. The addition to PET of more annual climate variables, or their interactions with PET, does not significantly improve the regression of mortality on PET shown in Equation 1, suggesting that their trends with mortality indicated in Table 2 could have arisen through inter-correlation. However, average spring temperature (Tave_sp), which shows no significant correlation with PET, is significant when added to PET as a regressor in Equation 1, outperforming other variables including annual, winter, summer and autumn average temperatures, as described in Table 3a. Note in Table 3a that Tave_sp is the only seasonal temperature demonstrating a significant effect in combination with PET. The model including PET and Tave_sp has the highest R-square (0.28) and lowest AIC score (-85.6), indicating a superior fit in comparison to the model based on PET and to the models combining PET with other seasonal temperatures.
The superior model has the form:

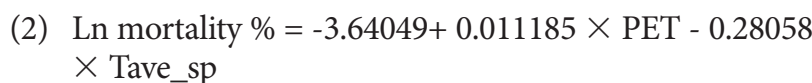

Fig. 3 displays partial regression residual leverage plots for this relationship. In each of the two leverage plots shown, the distance from a point to the solid sloping line of fit indicates the actual residual. The distance from a point to the hatched horizontal line of the mean mortality value shows what the residual error would be if the regressor were removed from the model. Interpretation of the figure involves judging whether the line of fit represents all the points significantly better than does the horizontal line. (The probability significance value $\mathrm{P}$ beneath each plot is the probability that this is not the case.) The hatched confidence curves on either side of the line of fit indicate whether the effect of the regressor is significant at the 0.05 probability level. If the curves cross the horizontal line, as shown for both regressors in Fig. 3, the effect is significant. These results suggest that mortality increases with high rates of annual evapotranspiration but is reduced by a separate effect of average spring temperature.

\section{Effect of climate on Armillaria root disease}

Inspection of dead planted lodgepole pine in the RLP trial identified Armillaria root disease as the most frequent probable cause of death $(71 \%)$, followed by root collar weevils (21\%), western gall rust (4\%), browsing (2\%) and miscellaneous other factors $(2 \%)$. The results reported below are restricted to effects on the probability of Armillaria attack at the plot level and on its frequency at the individual tree level within attacked plots.

Table $2 \mathrm{~b}$ summarizes relationships between individual annual climate variables and probabilities of attack at the plot and tree level by Armillaria root disease. The variables are ranked by R-square (U), which represents the proportion of the total variation in probability of plot attack explained by each climate variable. The trend of the response relative to the climate variable is indicated as positive (increasing) or negative (decreasing). The two evapotranspiration indices (PET and Eref) again rank highly, both for the probability of plot attack and for the proportion of trees infected within attacked plots. CMD ranks highest (with the lowest AIC value) for explaining variation in the proportion of trees infected in attacked plots, but performs more poorly for predicting probability of plot attack. Probabilities of Armillaria infection, both at the plot and tree level, significantly increase with PET, Eref, $\mathrm{CMD}, \mathrm{DD}<0$ and $\mathrm{AHM}$, and significantly decrease with CMI, MCMT, MAP and MAT.

Inclusion of more climate variables in the logistic regressions of plot-attack probability on PET or Eref identifies $\mathrm{DD}<0$ and MAT as significant additional regressors, both predicting a decrease in attack probability at warmer temperatures in addition to the increase with potential evapotranspiration. The positive relationship between attack and $\mathrm{DD}<0$ (degree days less than $0^{\circ} \mathrm{C}$ ) is consistent with the decrease in attack probability observed at higher levels of winter temperatures. When seasonal variables are substituted for $\mathrm{DD}<0$ and MAT, regressions are always improved by the inclusion of mean spring values as compared to annual, winter, summer or autumn means. Table $3 \mathrm{~b}$ shows the improvements result- 
Table 3. Test results for effects of potential evapotranspiration $\left(X_{1}\right)$ and seasonal temperatures $\left(X_{2}\right)$ on tree mortality and Armillaria attack

(a) Tree mortality \%

\begin{tabular}{|c|c|c|c|c|c|c|}
\hline \multicolumn{2}{|c|}{$\begin{array}{l}\text { Included } \\
\text { variables }\end{array}$} & \multicolumn{3}{|c|}{$\begin{array}{l}\text { Whole model tests } \\
\text { (standard least squares) }\end{array}$} & \multicolumn{2}{|c|}{$\begin{array}{l}\text { Effect tests: } \\
\text { Prob > F }\end{array}$} \\
\hline $\mathrm{X}_{1}$ & $\mathrm{X}_{2}$ & R-square & Prob $>$ F & AIC & $X_{1}$ & $\mathrm{X}_{2}$ \\
\hline PET & - & 0.214 & $<.0001$ & -81.4 & $<.0001$ & - \\
\hline PET & Tave_sp & 0.276 & $<.0001$ & -85.6 & $<.0001$ & 0.0147 \\
\hline PET & Tave_sm & 0.235 & $<.0001$ & -81.4 & $<.0001$ & 0.1657 \\
\hline PET & Tave_at & 0.246 & $<.0001$ & -82.6 & $<.0001$ & 0.0808 \\
\hline PET & Tave_wt & 0.224 & $<.0001$ & -80.3 & 0.0331 & 0.3469 \\
\hline
\end{tabular}

(b) Probability of plot attack by Armillaria

\begin{tabular}{|c|c|c|c|c|c|}
\hline \multicolumn{2}{|c|}{$\mathrm{X}$-variables } & \multicolumn{2}{|c|}{$\begin{array}{l}\text { Whole model tests } \\
\text { (logistic) }\end{array}$} & \multicolumn{2}{|c|}{$\begin{array}{l}\text { Effect likelihood ratio tests: } \\
\text { Prob > ChiSq }\end{array}$} \\
\hline $\mathrm{X}_{1}$ & $\mathrm{X}_{2}$ & $\begin{array}{l}\text { R-square } \\
\text { (U) }\end{array}$ & $\begin{array}{l}\text { Prob > } \\
\text { ChiSq }\end{array}$ & $\mathrm{X}_{1}$ & $\mathrm{X}_{2}$ \\
\hline PET & - & 0.126 & $<.0001$ & $<.0001$ & - \\
\hline PET & Tave_sp & 0.216 & $<.0001$ & $<.0001$ & $<.0001$ \\
\hline PET & Tave_sm & 0.174 & $<.0001$ & $<.0001$ & $<.0001$ \\
\hline PET & Tave_at & 0.172 & $<.0001$ & $<.0001$ & $<.0001$ \\
\hline PET & Tave_wt & 0.144 & $<.0001$ & 0.0072 & 0.0062 \\
\hline
\end{tabular}

(c) $\%$ of trees infected by Armillaria

\begin{tabular}{|c|c|c|c|c|c|c|}
\hline \multicolumn{2}{|c|}{$\begin{array}{l}\text { Included } \\
\text { variables }\end{array}$} & \multicolumn{3}{|c|}{$\begin{array}{c}\text { Whole model tests } \\
\text { (standard least squares) }\end{array}$} & \multicolumn{2}{|c|}{$\begin{array}{l}\text { Effect tests: } \\
\text { Prob > F }\end{array}$} \\
\hline $\mathrm{X}_{1}$ & $\mathrm{X}_{2}$ & R-square & Prob $>$ F & AIC & $\mathrm{X}_{1}$ & $\mathrm{X}_{2}$ \\
\hline PET & - & 0.334 & $<.0001$ & 43.1 & $<.0001$ & - \\
\hline PET & Tave_sp & 0.518 & $<.0001$ & 25.7 & $<.0001$ & $<.0001$ \\
\hline PET & Tave_sm & 0.488 & $<.0001$ & 29.4 & $<.0001$ & 0.0001 \\
\hline PET & Tave_at & 0.414 & $<.0001$ & 37.5 & $<.0001$ & 0.0072 \\
\hline PET & Tave_wt & 0.374 & $<.0001$ & 41.4 & 0.0328 & 0.0593 \\
\hline
\end{tabular}

ing from addition of the seasonal temperatures to PET. The highest Rsquare $(\mathrm{U})$ value of 0.22 is obtained by including PET and mean spring temperature (Tave_sp). The model has the following form:

(3) $\mathrm{P}=\left(1+\mathrm{e}^{\mathrm{Y}}\right)^{-1}$

Where:

$\mathrm{P}=$ probability ( 0 to 1$)$ of attack by Armillaria occurring within a 0.1 ha sub-plot

$$
\begin{aligned}
& \mathrm{e}=\text { the base of natural logarithms } \\
& \mathrm{Y}=12.70454-0.037946\left(\mathrm{X}_{1}\right) \\
& +1.50002\left(\mathrm{X}_{2}\right) \\
& \mathrm{X}_{1}=\text { PET and } \mathrm{X}_{2}=\text { Tave_sp }
\end{aligned}
$$

When other climate variables are included with PET to predict the percentage of trees infected in attacked whole-plots, a decrease in infection at warmer temperatures and an increase with potential evapotranspiration are again indicated. As was the case for mortality and probability of plot attack, more variation in infection is explained when mean spring temperature is included as compared to winter, summer, autumn or annual values (see Table 3c). The best model (R-square 0.52 and AIC 25.7) is described by the equation:
(4) Ln infection $\%=-14.00228$
$+0.039857 \times$ PET -1.27594
$\times$ Tave_sp

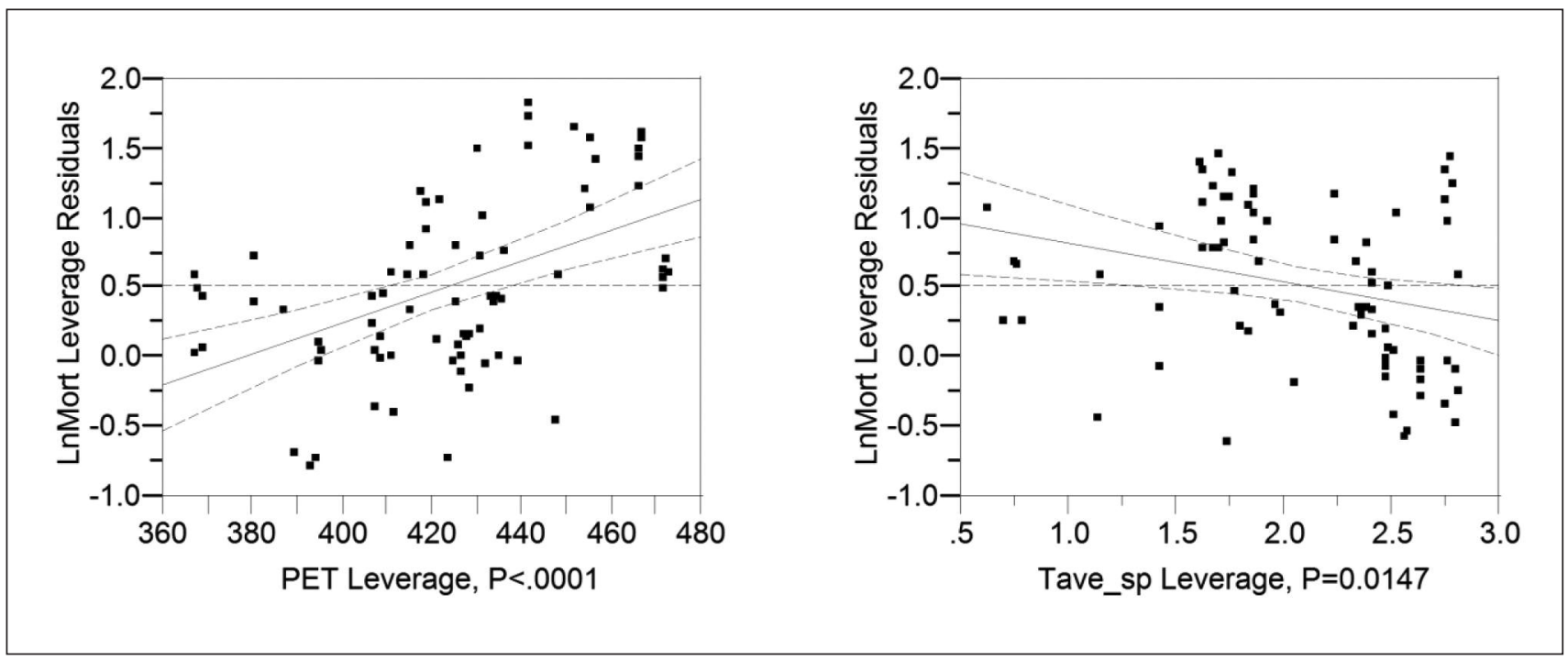

Fig. 3. Partial regressions for the effects of annual potential evapotranspiration (PET) and average spring temperature (Tave_sp) on mortality of planted stock. Mortality increases with potential evapotranspiration and decreases with spring temperature. 

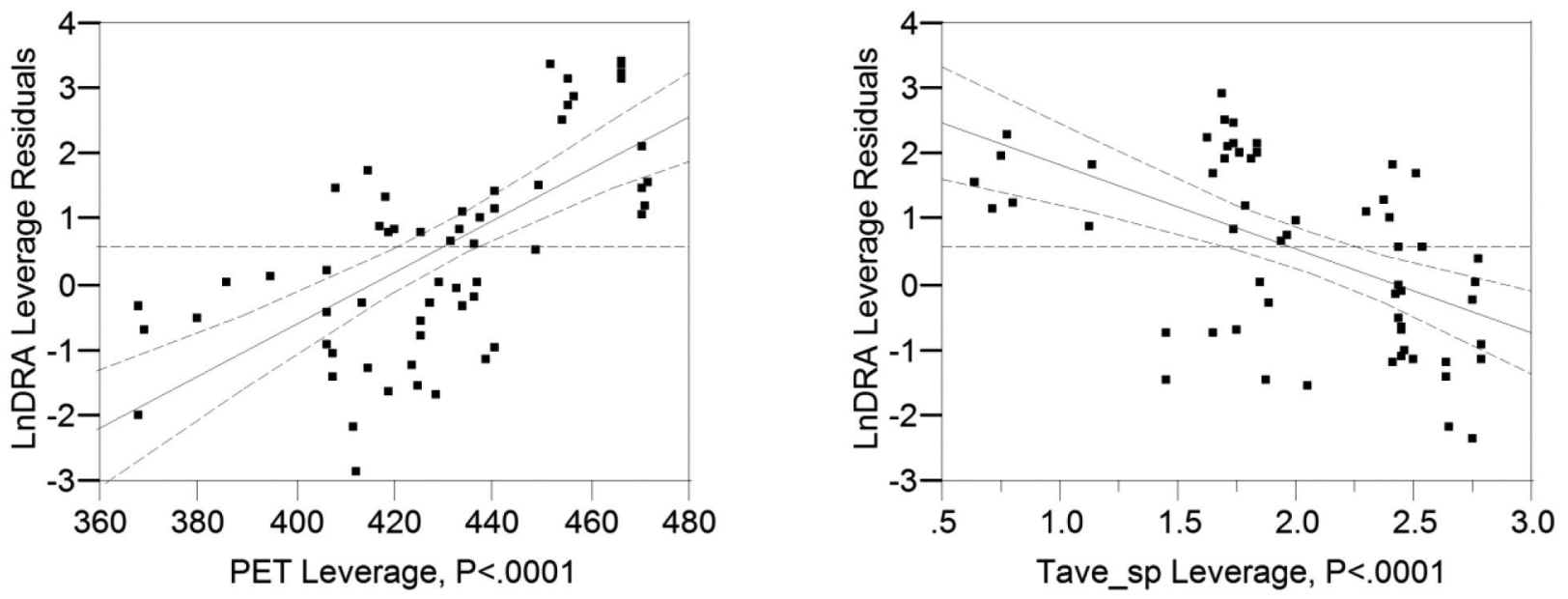

Fig. 4. Partial regressions for the effects of annual potential evapotranspiration (PET) and average spring temperature (Tave_sp) on percentage of planted trees infected by Armillaria root disease in attacked plots. Infection increases with potential evapotranspiration and decreases with spring temperature.

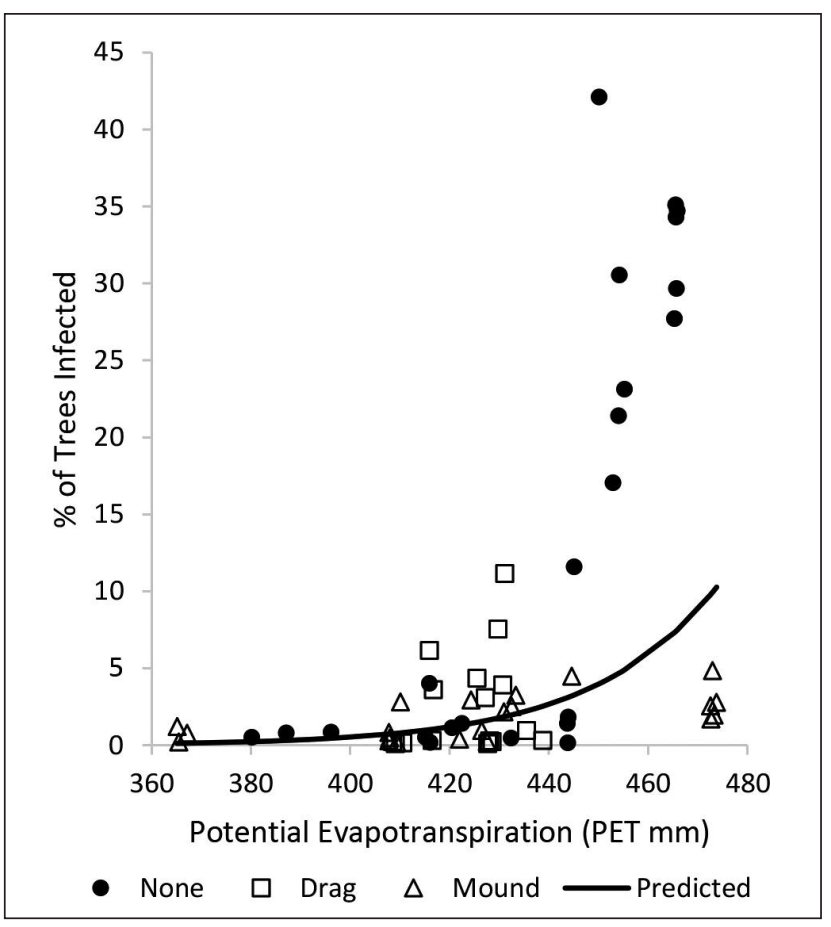

Fig. 5. Trend of the percentage of planted trees infected by Armillaria root disease in attacked sample plots with annual potential evapotranspiration. Observed values are shown relative to the trend predicted by Equation 4, with average spring temperature fixed at the mean value of $2^{\circ} \mathrm{C}$ estimated for the trial. Plots are differentiated by site preparation method.

Fig. 4 displays leverage plots for the effects of PET and Tave_sp. Actual infection values are compared in Fig. 5 to the trend of infection with PET predicted by Equation 4 . Note that the highest infection rates (exceeding 15\%) all occur in plots that received no mechanical site preparation treatment, suggesting that site treatment as well as climate may be affecting the response.

\section{Site quality and silvicultural treatments}

Table 4 summarizes the results of significance tests from MANOVA analyses of site and treatment effects on tree mortality and on tree infection rates within plots attacked by Armillaria. The tests were made with and without potential evapotranspiration and spring temperature being included in the analyses. Results are shown for the main effects of site factors (soil nutrient regime, soil moisture regime and natural sub-region (NSR)) and silvicultural treatments (mechanical site preparation, planting density and weeding). Between-plot climate effects (PET and Tave_sp) are always significant (Prob $>$ F less than 0.05) when tested with each of the site and treatment effects, and for brevity are not included in Table 4 .

Table 5 lists mean values for mortality and Armillaria infection percentages by levels of treatment and site factors. Least-squares means, calculated after PET and Tave_sp are taken into account as co-variates are also listed. Differences among the least-squares means are shown as calculated by the Tukey HSD test at the 0.05 probability level. All analyses and tests were based on logarithmic transformation of the response variables, but note that in Table 5 means are converted back to actual percentages.

Mortality is not significantly affected by soil nutrient class, but there is an indication that the percentage of trees infected by Armillaria is reduced on rich relative to poorer sites. Soil moisture significantly affects tree mortality and Armillaria infection, with both increasing on drier (submesic) sites. Mortality and Armillaria infection are higher in the Lower than in the Upper Foothills natural sub-regions, but the observed differences between sub-regions can be explained by differences in potential evapotranspiration and spring temperature.

Overall mortality on sites with no mechanical site preparation is significantly higher than on dragged or mounded sites. Average mean annual mortality rates across the whole RLP trial are $2.4 \%, 1.1 \%$ and $1.3 \%$ for non-treated, dragged and mounded plots respectively (see Table 5). The effects of site preparation, PET (or Eref) and Tave_sp appear additive. Addition of site preparation as an independent regressor term 
Table 4. Test results from multivariate analyses of site and treatment effects on tree mortality and infection by Armillaria

\begin{tabular}{|c|c|c|c|c|c|c|c|c|c|}
\hline \multirow[b]{2}{*}{ Effect } & \multirow[b]{2}{*}{ Included variables } & \multicolumn{4}{|c|}{ Tree mortality \% } & \multicolumn{4}{|c|}{$\%$ of trees infected by Armillaria } \\
\hline & & Exact $\mathrm{F}^{1}$ & NumDF $^{2}$ & DenDF $^{3}$ & Prob $>F^{4}$ & Exact $\mathrm{F}^{1}$ & NumDF $^{2}$ & DenDF $^{3}$ & Prob $>F^{4}$ \\
\hline \multirow[t]{2}{*}{ Nutrient } & Nutrient & 1.850 & 2 & 76 & 0.1642 & 8.110 & 2 & 43 & 0.0010 \\
\hline & Nutrient + PET + Tave_sp & 0.046 & 2 & 74 & 0.9549 & 5.653 & 2 & 41 & 0.0068 \\
\hline \multirow[t]{2}{*}{ Moisture } & Moisture & 7.194 & 3 & 75 & 0.0003 & 3.688 & 3 & 42 & 0.0191 \\
\hline & Moisture + PET + Tave_sp & 4.658 & 3 & 73 & 0.0049 & 2.877 & 3 & 40 & 0.0479 \\
\hline \multirow[t]{2}{*}{ NSR } & NSR & 7.086 & 1 & 77 & 0.0095 & 16.280 & 1 & 44 & 0.0002 \\
\hline & NSR + PET + Tave_sp & 3.123 & 1 & 75 & 0.0812 & 4.054 & 1 & 42 & 0.0505 \\
\hline \multirow[t]{2}{*}{ Site prep. } & SitePrep & 11.566 & 2 & 76 & $<.0001$ & 5.124 & 2 & 43 & 0.0101 \\
\hline & SitePrep + PET + Tave_sp & 17.561 & 2 & 74 & $<.0001$ & 10.279 & 2 & 41 & 0.0002 \\
\hline \multirow[t]{2}{*}{ Density } & Density & 0.520 & 4 & 74 & 0.7210 & 1.112 & 4 & 41 & 0.3641 \\
\hline & Density + PET + Tave_sp & 0.616 & 4 & 72 & 0.6527 & 0.487 & 4 & 39 & 0.7451 \\
\hline \multirow[t]{2}{*}{ Weed } & Weed & 0.225 & 1 & 78 & 0.6366 & 11.340 & 1 & 45 & 0.0016 \\
\hline & Weed + PET + Tave_sp & 0.156 & 1 & 76 & 0.6940 & 2.642 & 1 & 43 & 0.1114 \\
\hline
\end{tabular}

${ }^{1}$ F-value corresponding to the exact F-test

${ }^{2}$ Numerator degrees of freedom

${ }^{3}$ Denominator degrees of freedom

${ }^{4}$ Significance probability corresponding to the F-value (probabilities of 0.05 or less are typically considered as evidence that the effect is significant)

in Equation 2 increases the R-square from 0.28 to 0.50 and reduces the AIC from -86 to -112 . All three terms (PET, Tave_sp and site preparation method) are highly significant $(\mathrm{P}<0.0001)$. The model is the basis for Fig. 1d, except that Eref is substituted for PET because it is calculated internally by the climate model used to generate the maps. The resulting equation is:

(5) $\mathrm{Y}=-0.29759+0.0090145 \times$ Eref $-0.54918 \times$ Tave_sp $+0.44011 \times \operatorname{Prep}[\mathrm{a}-\mathrm{c}]-0.43347 \times \operatorname{Prep}[\mathrm{b}-\mathrm{c}]$

Where:

$\mathrm{Y}=\ln$ mortality \%

Eref $=$ Hargreaves reference evaporation $(\mathrm{mm}$ per year $)$

Tave_sp $=$ average spring temperature $\left({ }^{\circ} \mathrm{C}\right)$

Prep $=$ site preparation method

And when:

Prep $=$ None, $\mathrm{a}-\mathrm{c}=1$ and $\mathrm{b}-\mathrm{c}=0$

Prep $=$ Drag, $a-c=0$ and $b-c=1$

Prep $=$ Mound, $\mathrm{a}-\mathrm{c}=-1$ and $\mathrm{b}-\mathrm{c}=-1$

Site preparation also affects the percentage of trees infected with Armillaria in attacked plots, with and without evapotranspiration and spring temperature being taken into account. Inclusion of site preparation with PET and Tave_sp in Equation 4 increases the $\mathrm{R}^{2}$ from 0.52 to 0.71 and reduces the AIC from 25.7 to 0.2 . All three terms are highly significant (Prob $>\mathrm{F}$ less than 0.0001). The resulting model is described by Equation 6 . Both Equation 5 and Equation 6 are based on whole plots and ignore treatment effects other than site preparation.

(6) $\mathrm{Y}=-10.87135+0.03453 \times$ PET $-1.75654 \times$ Tave_sp

$+1.01475 \times$ Prep[a-c] $-0.99099 \times \operatorname{Prep}[\mathrm{b}-\mathrm{c}]$
Where:

$\mathrm{Y}=\ln$ infection \%

$\mathrm{PET}=$ potential evapotranspiration (mm per year)

Tave_sp $=$ average spring temperature $\left({ }^{\circ} \mathrm{C}\right)$

Prep $=$ site preparation method and the terms $\mathrm{a}-\mathrm{c}$ and

b-c are calculated as in Equation 5.

Planting density does not significantly affect tree mortality or Armillaria infection. Weeding reduces average juvenile mortality by a small, but statistically significant amount in the Lower Foothills, but not in the Upper Foothills. The effect is not significant when assessed across the entire trial. There is an indication that weeding reduces Armillaria infection in attacked stands, but the statistical significance of the effect is not maintained in the test where weeding and climate effects are both included (see Table 4).

Although logistic regression analyses indicate statistically significant effects of individual site and treatment factors on the probability of plot attack by Armillaria, and trends are generally consistent with those reported above for infection at the individual tree level, they explain relatively little of the variation in probability of attack with R-square $(\mathrm{U})$ values of less than $0.05{ }^{4}$

\section{Discussion}

Climate factors influencing juvenile mortality and Armillaria root disease

Juvenile mortality and Armillaria root disease increase with potential evapotranspiration occurring during the growing season, but there also appears to be an opposite effect whereby they decrease with increasing spring temperatures. Other climate variables are correlated with mortality and dis-

${ }^{4}$ See Table S4 in Supplementary Materials 
Table 5. Means of tree mortality and Armillaria infection percentages by site and treatment factors

\begin{tabular}{|c|c|c|c|c|c|}
\hline \multirow[b]{2}{*}{ Factor } & \multirow[b]{2}{*}{ Level } & \multicolumn{2}{|c|}{ Mortality \% } & \multicolumn{2}{|c|}{ Infection \% } \\
\hline & & Mean & $\begin{array}{l}\text { Least sq. } \\
\text { mean }\end{array}$ & Mean & $\begin{array}{c}\text { Least sq. } \\
\text { mean }\end{array}$ \\
\hline \multirow[t]{3}{*}{ Nutrient } & Poor & 1.27 & $1.56 \mathrm{~A}$ & 2.27 & $4.23 \mathrm{~A}$ \\
\hline & Medium & 1.82 & $1.57 \mathrm{~A}$ & 7.74 & $5.30 \mathrm{~A}$ \\
\hline & Rich & 1.67 & $1.69 \mathrm{~A}$ & 1.29 & $1.45 \quad \mathrm{~B}$ \\
\hline \multirow[t]{4}{*}{ Moisture } & Submesic & 2.90 & $3.01 \mathrm{~A}$ & 12.49 & $10.75 \mathrm{~A}$ \\
\hline & Mesic & 1.88 & $1.73 \mathrm{~A} \mathrm{~B}$ & 4.21 & $3.60 \mathrm{~A} \mathrm{~B}$ \\
\hline & Subhygric & 1.00 & $1.19 \quad \mathrm{~B}$ & 1.02 & $1.76 \quad \mathrm{~B}$ \\
\hline & Hygric & 1.34 & $1.26 \mathrm{~A} \mathrm{~B}$ & 4.41 & $3.12 \mathrm{~A} \mathrm{~B}$ \\
\hline \multirow[t]{2}{*}{ NSR } & Lower & 2.05 & $1.95 \mathrm{~A}$ & 7.60 & $5.46 \mathrm{~A}$ \\
\hline & Upper & 1.36 & $1.40 \mathrm{~A}$ & 1.64 & $2.17 \mathrm{~A}$ \\
\hline \multirow[t]{3}{*}{ Site prep. } & None & 2.40 & $2.50 \mathrm{~A}$ & 6.48 & $6.70 \mathrm{~A}$ \\
\hline & Drag & 1.12 & $1.05 \mathrm{~B}$ & 3.63 & $1.54 \quad \mathrm{~B}$ \\
\hline & Mound & 1.35 & 1.37 & 1.50 & 2.12 \\
\hline \multirow[t]{5}{*}{ Density } & 816 & 1.98 & $1.94 \mathrm{~A}$ & 6.01 & $4.75 \mathrm{~A}$ \\
\hline & 1111 & 1.59 & $1.63 \mathrm{~A}$ & 5.30 & $3.86 \mathrm{~A}$ \\
\hline & 1600 & 1.43 & $1.38 \mathrm{~A}$ & 3.68 & $3.11 \mathrm{~A}$ \\
\hline & 2500 & 1.61 & $1.63 \mathrm{~A}$ & 2.61 & $3.07 \mathrm{~A}$ \\
\hline & 4444 & 1.42 & $1.45 \mathrm{~A}$ & 1.76 & $2.52 \mathrm{~A}$ \\
\hline \multirow{2}{*}{ Weed } & Leave & 1.57 & $1.57 \mathrm{~A}$ & 3.70 & $3.70 \mathrm{~A}$ \\
\hline & Weed & 1.53 & $1.53 \mathrm{~A}$ & 2.42 & $2.42 \mathrm{~A}$ \\
\hline
\end{tabular}

${ }^{1}$ Levels not connected by the same letter within the same factor are significantly different.

ease, but their apparent effects diminish or disappear in regression analyses that include potential evapotranspiration and spring temperature as independent variables. Results suggest physiological stress related to evapotranspiration as a probable cause of juvenile mortality and susceptibility to rootdisease. They are consistent with reports in the literature suggesting that stress can be induced by high drying rates (e.g., Monserud et al. 2008), but also by reduced moisture uptake by roots associated with cold soil temperatures (e.g., Henson 1952).

The high incidence of Armillaria in the RLP trial was cause of particular management concern and facilitated a basic examination of the relationship between tree infection rates and climate variables. The study did not investigate in detail the large number of other pathogens to which lodgepole pine is known to be susceptible, or the complex interlinkages between pathogen dynamics, host susceptibilities and climate. The methodology used did not permit definitive confirmation of which pathogens or abiotic agents (or combination thereof) actually killed the sampled trees. Given the potential for health problems to increase with climate change, further research is needed to provide a more comprehensive understanding of all damage agents and their relationships to pine mortality and climate.

\section{Prediction of juvenile mortality from climate variables}

Two climate variables (annual evapotranspiration and average spring temperature) explain almost 30\% (R-square 0.28 ) of the overall between-plot variation in planted stock mortal- ity observed in the RLP trial. If the site preparation method is taken into account, the proportion of explained variation increases to $50 \%$ (R-square 0.50 ).

The model described by Equation 5 was used as a basis for mapping the risk of juvenile mortality. Three classes of risk are recognized in the mortality risk map (Fig. 1d) based on the estimated mean annual mortality of stock planted with no mechanical site preparation: High (mortality $>3 \%$ ), Low (mortality $<2 \%$ ) and Intermediate. If mean annual mortality levels observed over 12 years are continued up to stand ages of 30 years, as suggested by the Ives and Rents (1993) study, then at annual rates of $3 \%$ much of the investment in planted stock will be lost and regeneration will likely fail unless prolific natural regeneration is achieved. The high risk class shown in Map 1 occupies $27 \%$ of the study area. It indicates where regeneration performance failure is most likely, assuming climatic conditions similar to those experienced in the last decade. The map does not take into account local soil-site variation, or future climate change.

\section{Selection of reforestation practices to reduce mortality and root disease}

Planting density does not show a significant effect on tree mortality or Armillaria infection rates during the first 11 to 12 years following planting. Weeding has a significant but modest effect on mortality in the Lower Foothills. Mechanical site preparation appears to have a pronounced and beneficial effect on planted stock survival and prevention of Armillaria root disease, with good potential for ameliorating adverse climatic effects in juvenile stands. The beneficial effect may result from improved soil water relations and /or infected roots being brought to the soil surface. Drag scarification can also encourage plentiful natural regeneration at densities capable of offsetting high mortality should it occur (Johnstone 1976, Dempster and Meredith 2014).

The site preparation results of this study are consistent with the finding by Landhäusser (2009) that planted pine seedlings in the Upper Foothills had lower mortality on soils that had been mechanically prepared; but the possibility that the site preparation effect may be confounded with site variation in the RLP trial has not been totally eliminated. The effect requires further investigation and testing. Re-measuring the trial established by Landhäusser (2009) would facilitate evaluation of the long-term effects of experimentally controlled harvesting and site preparation methods on the survival, growth and health of planted and naturally regenerated lodgepole pine 17 or more years after harvesting.

\section{Comparison with an earlier study of natural regeneration}

The RLP study has focused on planted lodgepole pine, and assessment of trends in natural regeneration has so far been constrained by ingress delay and variability. The earlier study by Ives and Rentz (1993) assessed factors affecting the survival of immature lodgepole pine and recorded mortality rates in natural regeneration. The Ives data shows generally similar trends to those of the RLP trial in the relationship between mortality and climate variables, but some differences in responses between the two trials are noteworthy and described in more detail elsewhere. ${ }^{5}$ As in the RLP trial,

${ }^{5}$ See Table S3, Fig. S3 and accompanying notes in Supplementary Materials 
potential evapotranspiration (PET and Eref) have the highest correlations with average annual mortality in the Ives data, and mortality is inversely related to mean coldest month temperature (MCMT). Differences in responses between the two trials (e.g., the correlation of $\mathrm{DD}<0$ with mortality in the Ives data is very weak and opposite in sign to that shown in the RLP data) may more reflect geographic variation in correlations between climate variables than differences in responses between natural and planted regeneration.

\section{Conclusions}

- Without abundant natural regeneration or appropriate site preparation, high and sustained juvenile mortality of planted lodgepole pine is likely to jeopardize reforestation investments and success in areas of the Alberta foothills identified as having high climatic mortality risk.

- Juvenile mortality and Armillaria root disease increase with higher annual rates of potential evapotranspiration, but decrease with higher spring or winter temperatures.

- Potential evapotranspiration rate and spring or winter temperatures calculated by available climate models can be used to predict juvenile mortality risk. Over the geographic range of the RLP study area, annual potential evapotranspiration rate and average spring temperature provide the best combination of independent climate variables for prediction.

- Mechanical site preparation aimed at countering mortality and disease of planted stock with improved soil conditions, or encouraging high density natural regeneration, appears to have good potential for ameliorating adverse climatic effects in juvenile stands. Further experimentation is required to verify and explain its apparent effects.

\section{Acknowledgements}

This study is the result of long-term commitment, financial support and technical input by the following organizations: Alberta Newsprint Company, Blue Ridge Lumber, Canadian Forest Products, Canadian Forest Service Northern Forestry Centre, Edson Forest Products, Forest Resource Improvement Association of Alberta, Forestry Division of the Alberta Ministry of Agriculture and Forestry, fRI Research, Hinton Wood Products, Millar Western Forest Products, Spray Lake Sawmills, Sundre Forest Products and Weyerhaeuser Company Alberta Forestlands. The project was managed by Sharon Meredith (Executive Director, Forest Growth Organization of Western Canada). Julie Duval and Joshua Crough (fRI Research) provided GIS and mapping support.

\section{References}

Alberta Forest Genetic Resources Council. (2006). Climate change and genetic resources. Brochure, Edmonton, Alberta. 2 p. Available from: http://abtreegene.com [accessed 20 December 2016].

Alberta Sustainable Resource Development. (2007). Mountain pine beetle management strategy. Pub. No. T/154, Edmonton, Alberta. 20 p. Available from: http://www1.agric.gov.ab.ca/\$department/deptdocs.nsf/all/formain15803/\$file/MPB-ManagementStrategy-Dec2007.pdf [accessed 10 March 2017]

Archibald, J.H., G.D. Klappstein and I.G. Corns. (1996). Field guide to ecosites of southwestern Alberta. Special Report 8. Canadian Forest Service, Northwest Region, Northern Forestry Centre, Edmonton, Alberta. 492 p.
Beckingham, J.D., I.G. Corns and J.H. Archibald. (1996). Field guide to ecosites of west-central Alberta. Special Report 9. Canadian Forest Service, Northwest Region, Northern Forestry Centre, Edmonton, Alberta. 540 p.

Carroll, A.L., J. Regniere, J.A. Logan, S.W. Taylor, B.J. Bentz and J.A. Powell. (2006). Impacts of climate change on range expansion by the mountain pine beetle. Mountain Pine Beetle Initiative Working Paper 2006-4, Canadian Forest Service, Pacific Forestry Centre, Victoria. B.C.

Cerezke, H.F. (1973). Survival of the weevil Hylobius warreni in lodgepole pine stumps. Can. J. Forest Res. 3: 367-372. doi:10.1139/x73-054.

Chen, H.Y.H. and Y. Luo. (2015). Net aboveground biomass declines of four major forest types with forest ageing and climate change in western Canada's boreal forests. Global Change Biol. doi: 10.1111/gcb.12994.

Chhin, S., E.H. Hogg, V.J. Lieffers and S. Huang. (2008). Potential effects of climate change on the growth of lodgepole pine across diameter size classes and ecological regions. Forest Ecol. Manag. 256: 1692-1703. doi:10.1016/j.foreco.2008.02.046.

Corns, I., D.J. Downing and T.I. Little. (2005). Field guide to ecosites of west-central Alberta: Supplement for managed forest stands up to 40 years of age. Canadian Forest Service, Northern Forestry Centre, Edmonton, Alberta. Special Report 15. 140 p. Available from: http://cfs.nrcan.gc.ca/pubwarehouse/pdfs/25327.pdf [accessed 22 December 2016].

Cortini, F., P.G. Comeau, J.O. Boateng and L. Bedford. (2010). Yield implications of site preparation treatments for lodgepole pine and white spruce in northern British Columbia. Forests 1(1): 25-48. doi:10.3390/f1010025.

Dempster, W.R. and S. Meredith. (2014). A discussion of best management practices for reforestation following harvesting of lodgepole pine in the Alberta foothills. Forest. Chron. 90(6): 763-770. doi: $10.5558 / \mathrm{tfc} 2014-148$

Erickson, A., C. Nitschke, N. Coops, S. Cumming and G. Stenhouse. (2015). Past-century decline in forest regeneration potential across a latitudinal and elevational gradient in Canada. Ecol. Model. 313: 94-102. doi:10.1016/j.ecolmodel.2015.06.027.

Fleming, R.L., T.A. Black and R.S. Adams. (1996). Site preparation effects on Douglas-fir and lodgepole pine water relations following planting in a pinegrass-dominated clearcut. Forest Ecol. Manag. 83: 47-60. doi:10.1016/0378-1127(95)03701-2.

Heineman, J.L., D.L. Sachs, W.J. Mather and S.W. Simard. (2010). Investigating the influence of climate, site, location and treatment factors on damage to young lodgepole pine in southern British Columbia. Can. J. Forest Res. 40: 1109-1127. doi:10.1139/x10-55.

Henson, W.R. (1952). Chinook winds and red belt injury to lodgepole pine in the Rocky Mountain parks area of Canada. Forest. Chron. 28(1): 62-64. doi:10.5558/tfc28062-1.

Huang, S., R.A. Monserud, T. Braun, H. Lougheed and O. Bakowsky. (2004). Comparing site productivity of mature fire-origin and post-harvest juvenile lodgepole pine stands in Alberta. Can. J. Forest Res. 34: 1181-1191. doi:10.1139/x04-009.

Hogg, E.H. (1994). Climate and the southern limit of the western Canadian boreal forest. Can. J. Forest Res. 24: 1835-1845. doi:10.1139/x94-237.

Hogg, E.H. (1997). Temporal scaling of moisture and the forestgrassland boundary. Agr. Forest Meteorol. 84: 115-122. doi:10.1016/ S0168-1923(96)02380-5.

Ives, W.G. and C.L. Rentz. (1993). Factors affecting the survival of immature lodgepole pine in the foothills of west-central Alberta. Forestry Canada Information Report NOR-X-330. Northern Forestry Centre, Edmonton, Alberta. 49 p. Available from: http://cfs.nrcan.gc.ca/bookstore_pdfs/11817.pdf [accessed 22 December 2016]. 
Johnstone, W.D. (1976). Ingress of lodgepole pine and white spruce regeneration following logging and scarification in west-central Alberta. Canadian Forest Service, Northern Forestry Research Centre, Edmonton, Alberta. Information Rep. NOR-X-170.

Klopfenstein, N.B., M.-S. Kim, J.W. Hanna, B.A. Richardson and J.E. Lundquist. (2009). Approaches to predicting potential impacts of climate change on forest disease: an example with Armillaria root disease. Rocky Mountain Research Station, Fort Collins, CO: U.S. Department of Agriculture, Forest Service Res. Pap. RMRS-RP-76. 10 p. Available from: https://fs.fed.us/rm/pubs/rmrs_rp076.pdf [accessed 22 December 2016].

Landhäusser, S.M. (2009). Impact of slash removal, drag scarification and mounding on lodgepole pine cone distribution and seedling regeneration after cut-to-length harvesting on high elevation sites. Forest Ecol. Manag. 258: 43-49. doi:10.1016/j.foreco. 2009.03.045.

La Porta, N., P. Capretti, I.M Thomsen, R. Kasanan, A.M. Hietala and K. Von Weissenberg. (2008). Forest pathogens with higher damage potential due to climate change in Europe. Can. J. Plant Pathol. 30 (2): 177-195. doi:10.1080/07060661.2008.10540534.

Mallett, K.I. (1990). Host range and geographic distribution of Armillaria root rot pathogens in the Canadian prairie provinces. Can. J. Forest Res. 20: 1859-1863. doi:10.1139/x90-249.

Mather, W.J., S.W. Simard, J.L. Heineman and D.L. Sachs. (2010). Decline of planted lodgepole pine in the southern interior of British Columbia. Forest. Chron. 86: 4, 484-497. doi:10.5558/tfc86484-4.

Monserud, R.A., Y. Yang, S. Huang and N. Tchebakova. (2008). Potential change in lodgepole pine site index and distribution under climate change in Alberta. Can. J. Forest Res. 38: 343-352. doi:10.1139/X07-166.

Nordin, V.J. (1954). Forest pathology in relation to the management of lodgepole pine in Alberta. Forest. Chron. 30(3): 299-306. doi:10.5558/tfc30299-3.

Peng, C., Z. Ma, X. Lei, Q. Zhu, H. Chen, W. Wang, S. Lui, W. Li, $X$. Feng and $X$. Zhou. (2011). A drought induced pervasive increase in tree mortality across Canada's boreal forests. Nat. Clim. Change (1). doi: 10.1038/NCLIMATE1293.
Powell, J.M. (1966). Distribution and outbreaks of Dendroctonus ponderosae in forests of Western Canada. Canadian Department of Forestry, Information Report A-X-2, Forest Research Laboratory, Calgary, Alberta. 19 p.

SAS Institute Inc. (2002). JMP statistics and graphics guide, version 5. Cary, NC: $707 \mathrm{p}$.

Schneider, R.R., A. Hamann, D. Farr, X. Wang and S. Boutin. (2009). Potential effects of climate change on ecosystem distribution in Alberta. Can. J. Forest Res. 39: 1001-1010. doi:10.1139/X09-033.

Thorpe, H.C. and L.D. Daniels. (2012). Long-term trends in tree mortality rates in the Alberta foothills are driven by stand development. Can. J. Forest Res. 42: 1687-1696. doi:10.1139/x2012-104.

Van Mantgem, P.J., N.L. Stephenson, J.C. Byrne, L.D. Daniels, J.F. Franklin and P.Z. Fule. (2009). Widespread increase of tree mortality rates in the western United States. Science 323: 521-523. doi:10.1126/science.1165000.

Wang, T., A. Hamann, D. Spittlehouse and C. Carroll. (2016). Locally downscaled and spatially customizable climate data for historical and future periods for North America. PLoS ONE 11(6): e0156720. doi:10.1371/journal.pone.0156720.

Whitney, R.D. and M.T. Dumas. 1994. Minimizing losses to Armillaria root rot in Ontario spruce. Nat. Resources Canada, Can. For. Serv., Great Lakes Forestry Centre, Sault Ste. Marie, Ontario. Frontline Forestry Research Applications Tech. Note No. 84. Available from: http://cfs.nrcan.gc.ca/pubwarehouse/pdfs/9259.pdf [accessed 22 December 2016].

Woods, A., K.D. Coates and A. Hamann. (2005). Is an unprecedented Dothistroma needle blight epidemic related to climate change? BioScience 55 (9): 761-769.

Zhang, J., S. Huang and F. He. (2015). Half-century evidence from western Canada shows forest dynamics are primarily driven by competition followed by climate. Proceedings of the National Academy of Sciences of the USA 112 (13): 4009-4014. doi:10.1073/pnas. 1420844112. 